2003

\title{
Therapeutic Jurisprudence and Outpatient Commitment Law: Kendra’s Law as Case Study
}

Michael L. Perlin

New York Law School, michael.perlin@nyls.edu

Follow this and additional works at: http://digitalcommons.nyls.edu/fac_articles_chapters

Part of the Disability Law Commons, and the Law and Psychology Commons

\section{Recommended Citation}

9 Psychology, Public Policy \& Law 183-208 (2003)

This Article is brought to you for free and open access by the Faculty Scholarship at DigitalCommons@NYLS. It has been accepted for inclusion in Articles \& Chapters by an authorized administrator of DigitalCommons@NYLS. 


\title{
THERAPEUTIC JURISPRUDENCE AND OUTPATIENT COMMITMENT LAW Kendra's Law as Case Study
}

\author{
Michael L. Perlin \\ New York Law School
}

\begin{abstract}
This article considers the implications of assisted outpatient commitment laws (OPC), with specific focus on New York's "Kendra's Law" through the lens of therapeutic jurisprudence (TJ). In this article, the author offers perspectives on the relationship between involuntary civil commitment, outpatient commitment, and the concept of the "least restrictive alternative"; considers pertinent empirical research, and looks at OPC's controversial relationship to forced drugging. Here, the civil libertarian critique is briefly considered, as well as the MacArthur Research Network research. Finally, the author looks closely at Kendra's Law, providing a brief overview of the law itself, and identifying some "pressure points" and pivotal issues, and considers the TJ implications of Kendra's Law, to determine how it "fits" into the public's "take" on all of mental disability law.
\end{abstract}

One of the most remarkable recent developments in legal scholarship has been the extent to which Therapeutic Jurisprudence (TJ) ${ }^{1}$ has flourished in a wide variety of legal areas, spanning the academy from gay rights to contracts

This article is adapted from a paper presented at the Third Conference of the International Network on Therapeutic Jurisprudence, Cincinnati, Ohio, May 2001. Portions of it draw on papers presented at the Association of American Law Schools' annual meeting (San Francisco, January 2001), the International Academy of Law and Mental Health's annual meeting (Siena, Italy, July 2000), a Grand Rounds Seminar at Kirby Forensic Psychiatric Center (New York City, December 2000), and at the New York State Office of Court Administration Court Update conferences in Rochester, New York (November 1999), Saratoga, New York (January 2000), and Rochester, New York (October 2000).

I thank Jenna Anderson for her exceptional research assistance, and Bruce Winick for his helpful and insightful comments.

Correspondence concerning this article should be addressed to Michael L. Perlin, New York Law School, 57 Worth Street, New York, New York 10013. E-mail: mperlin@nyls.edu

${ }^{1}$ Therapeutic jurisprudence presents a new model by which we can assess the ultimate impact of case law and legislation that affects mentally disabled individuals, studying the role of the law as a therapeutic agent, recognizing that substantive rules, legal procedures and lawyers' roles may have either therapeutic or anti-therapeutic consequences, and questioning whether such rules, procedures, and roles can or should be reshaped so as to enhance their therapeutic potential, while not subordinating due process principles. Michael L. Perlin, "For the Misdemeanor Outlaw", The Impact of the ADA on the Institutionalization of Criminal Defendants with Mental Disabilities, 52 Alabama L. Rev. 193, 228 (2000). See generally, Therapeutic Jurisprudence: The Law as a Therapeutic Agent 121, 122 (David Wexler ed. 1990) (Therapeutic Agent); Essays in TheraPeutic Jurisprudence (David B. Wexler \& Bruce J. Winick eds. 1991); LaW in a Therapeutic Key: Recent Developments in Therapeutic Jurisprudence (David B. Wexler \& Bruce J. Winick, eds. 1996) [hereinafter Therapeutic Key)]; Therapeutic Jurisprudence Applied: Essays on Mental Health Law (Bruce J. Winick ed. 1997); David B. Wexler, Putting Mental Health Into Mental Health Law: Therapeutic Jurisprudence, 16 L. \& Hum. Behav. 27 (1992.) 
law. ${ }^{2}$ I applaud this expansionism, and have no question in my mind that this has been a salutary development-not simply for legal scholarship, but for legal pedagogy, and, most important, for the practice of law. ${ }^{3}$

With that in mind, this paper returns to basic principles, and to the application of TJ to mental disability law. ${ }^{4}$ I do this because the specific question that I am addressing here-the implications of assisted outpatient commitment laws (AOPC), with specific focus on New York's "Kendra's Law"5-appears to be a particularly apt candidate for a TJ analysis. ${ }^{6}$

Kendra's Law is one of those state-specific statutes whose impact will inevitably extend beyond the one jurisdiction in which it is law. New York is far from the first state to experiment with AOPC $\mathrm{law}^{7}$ (although that is something that the unsuspecting reader would not know from the press coverage). However, because of the sensational series of events that led to the introduction and passage of the law- the vivid and horrifying facts of Kendra Webdale's death, the tortured life of her killer Andrew Goldstein, the saturation publicity given to the case ${ }^{8}$ and the way it became the focal point for so much political maneuvering in Albany ${ }^{9}$ - it has developed a public "following" that none of its predecessors shared. ${ }^{10}$

${ }^{2}$ See, e.g., Kay Kavanagh, Don't Ask, Don't Tell: Deception Required Disclosure Denied, 1 Psychol., Pub. Pol'y, \& L. 142 (1995); Jeffrey L. Harrison, Class, Personality, Contract, and Unconscionability, 35 WM. \& MARY L. Rev. 445 (1994).

${ }^{3}$ On how our teaching affects legal practice, see Michael L. Perlin, Stepping Outside the Box: Viewing Your Client in a Whole New Light, 37 CAL. W. L. Rev. 65 (2000); Michael L. Perlin A Law of Healing, 68 U. CIN. L. REv. 407 (2000) [Perlin, Healing].

${ }^{4}$ See e e.g., Michael L. Perlin, The Hidden Prejudice: Mental Disability on Trial (2000); Michael L. Perlin, Therapeutic Jurisprudence: Understanding the Sanist and Pretextual Bases of Mental Disability Law, 20 N. Eng. J. Crim. \& Crv. Confinement 369 (1994); Michael L. Perlin, et al., Therapeutic Jurisprudence and the Civil Rights of Institutionalized Mentally Disabled Persons: Hopeless Oxymoron or Path to Redemption? 1 Psychol., Pub. Pol'y \& L. 80 (1995), reprinted in THERAPEUTIC KeY, supra note 1, at 739; Bruce Winick, The Jurisprudence of Therapeutic Jurisprudence, 3 Psychol., Pub. Pol'y \& L. 184 (1997); Therapeutic Agent, supra note 1; David Wexler \& Bruce Winick, Therapeutic Jurisprudence as a New Approach to Mental Health Law Policy Analysis and Research, 45 U. Miami L. Rev. 979 (1991); Michael L. Perlin, What Is Therapeutic Jurisprudence?, 10 N.Y.L. ScH. J. Hum. RTs. 623 (1993); David Finkelman \& Thomas Grisso, Therapeutic Jurisprudence: From Idea to Application, 20 N. Eng. J. CRim. \& Civ. Confinement 243 (1994); David Wexler, An Orientation to Therapeutic Jurisprudence, 20 N. ENG. J. CRIM. \& Civ. Confinement 259 (1994); Bruce Sales \& Daniel Shuman, Mental Health Law and Mental Health Care: Introduction, 64 Am. J. ORTHOPSYChiATRY 172 (1994); David Wexler, Reflections on the Scope of Therapeutic Jurisprudence, 1 Psychol., PuB. PoL'y \& L. 220 (1995); Wexler, supra note 1; David Wexler, Therapeutic Jurisprudence: New Directions in Law/Mental Health Scholarship, in MenTAL Health Law: Research, Policy and Services 357 (Bruce Sales \& Saleem Shah eds. 1996).

${ }^{5}$ N.Y. Ment. Hyg. L. § 9.60.

${ }^{6}$ For an overview of the proliferation of legal and behavioral issues that have been the recent subject of therapeutic jurisprudence analyses, see 1 Michael L. Perlin, Mental Disability Law: Civil and Criminal, § 2D-3, at 534-41 (2d ed. 1998), and $i d$. at 96-106 (2001 Supp.).

${ }^{7}$ Id. at $\S 2 \mathrm{C}-7.3$, at $491-99$,

${ }^{8}$ A "KENDRA WEBDALE" search on WESTLAW (database: PAPERS) reveals a universe of 205 articles (April 24, 2001).

${ }^{9}$ See e.g., John Caher, Leaders Agree on Kendra's Law, Albany Times-Union (Aug. 4, 1999), at B2.

${ }^{10}$ These laws, however, have been studied extensively. See infra text accompanying notes $31-48$. 
Kendra's Law's day-to-day operationalization, the on-going constitutional challenges, ${ }^{11}$ the law's potential impact on the delivery of other mental health services in the state, and - most important - the inevitability of a "mistake" (a case in which denial of a Kendra's Law commitment is followed by the commission of a notorious criminal act, or a case in which entry of a Kendra's Law commitment is followed by a patient developing neuroleptic malignant syndrome or some other potentially-fatal antipsychotic drug side effect because of a misdiagnosis or an error in prescription or medication dispensation) all make it inevitable that it will become the centerpiece of the next mental health law debate. $^{12}$

It is thus especially important that a discussion of Kendra's Law also provide a national perspective as well as background on OPC - and how, for decades, OPC has been the paradigm trompe d'oeil illusion of mental disability law. In this paper I will do the following: First, I will offer some perspectives on the relationship between involuntary civil commitment and outpatient commitment, with a few brief words about how all of this relates to the concept of the "least restrictive alternative" (LRA) ${ }^{13}$ Then, I will consider some of the empirical research that has been done on outpatient commitment laws in other jurisdictions-most notably, North Carolina - and focus on both the issues that seemed to matter whether OPC "worked" and on the impact OPC may have had on "revolving door" commitments. ${ }^{14}$ After that, I will look at the most controversial aspect of outpatient commitment: its relationship to forced drugging. ${ }^{15}$ Here, I will consider briefly the civil libertarian critique of OPC/forced drugging laws; I will take a brief look at some important recent developments, and I will also briefly mention the state-ofthe-art research done by the MacArthur Research Network on Mental Health and weigh some of its pertinent conclusions. ${ }^{16}$

Finally, I will look closely at Kendra's Law. Here, I will provide a brief overview of the law itself, and will identify some "pressure points" and pivotal

${ }^{11}$ On some of the enforced medication issues that are at the core of Kendra's Law, the NY Court of Appeals has relied on state constitutional law so as to provide persons with mental disabilities far more constitutional rights than they might receive under the federal constitution. See Rivers v. Katz, 504 N.Y.S. 2d 74 (1986).

${ }^{12}$ On the way one vivid case inevitably overwhelms statistical data of hundreds or thousands of other less vivid cases, see generally, Michael L. Perlin, "There's No Success like Failure/and Failure's No Success at All”: Exposing the Pretextuality of Kansas v. Hendricks, 92 Nw. U. L. Rev. 1247, 1256 (1998); Michael L. Perlin, "The Borderline Which Separated You From Me": The Insanity Defense, the Authoritarian Spirit, the Fear of Faking, and the Culture of Punishment, 82 IowA L. Rev. 1375, 1417 (1997).

See generally, National Ass'n of State Mental Health Program Directors, Technical Report on Involuntary Outpatient Commitment 15 (Aug. 2001) (Technical Report) ("Recent attention on [OPC] has been fueled by concerns with societal violence and inflamed by high profile cases. Policy changes should not be based solely on these few cases, but instead should derive from a firm foundation of research and experience").

${ }^{13}$ See infra Part I.

${ }^{14}$ See infra Part II.

${ }^{15}$ See infra Part III.

${ }^{16}$ See e.g., Violence and Mental Disorder: Developments in Risk Assessment (John Monahan \& Henry Steadman, eds. 1994). 
issues in the law. ${ }^{17}$ I believe that there are ambiguities in some of the "pressure points" that cry out for resolution, and that the appellate disposition of some of the pivotal issues will provide some clues as to the ultimate "real life" impact of Kendra's Law. ${ }^{18}$ Finally, I will consider the TJ implications of Kendra's Law, in part, in an effort to determine how it "fits" into the public's "take" on all of mental disability law. ${ }^{19}$

\section{Involuntary Civil Commitment and Outpatient Commitment ${ }^{20}$}

\section{A. The "LRA" Roots}

Trailblazing constitutional involuntary civil commitment cases such as Lessard v. Schmidt - the 1972 Wisconsin federal court decision that struck down that state's old civil commitment code ${ }^{21}$ and served as the model for involuntary civil commitment revisions in nearly every state ${ }^{22}$ - first applied the concept of the "LRA" to the involuntary civil commitment process. ${ }^{23}$ The theory was this: As "the most basic and fundamental right" is "the right to be free from unwanted restraint," the court concluded that "persons suffering from the condition of being mentally ill, but who are not alleged to have committed any crime, cannot be totally deprived of their liberty if there are less drastic means for achieving the same basic goal." 24

The Lessard court placed the burden for exploring alternatives to institutionalization on the party recommending full-time involuntary hospitalization, and ordered that that party prove:

(a) what alternatives are available; (b) what alternatives were investigated; and (c) why the investigated alternatives were not deemed suitable. These alternatives include voluntary or court-ordered out-patient treatment, day treatment in a hospital, night treatment in a hospital, placement in the custody of a friend or relative, placement in a nursing home, referral to a community mental health clinic, and home health aide services. ${ }^{25}$

Other jurisdictions subsequently adopted Lessard's reasoning in their commitment codes. Moreover, other courts quickly expanded the scope of the LRA doctrine beyond involuntary civil commitment decision making ${ }^{26}$ to include

17 See infra Part IV.

18 See infra Part V.

${ }^{19}$ See supra Part VI.

${ }^{20}$ This section is generally adapted from Michael L. Perlin, "Their Promises of Paradise". Institutional Segregation, Community Treatment, the ADA, and Olmstead v. L.C., 37 Hous. L. REv. 999, 1010-16 (2000).

21349 F. Supp. 1078 (E.D. Wis. 1972).

22 See generally, 1 PERLIN, supra note 6, § 2A-4.4a, at 131-32.

${ }^{23} I d$., $\$ 2 \mathrm{C}-5.3 \mathrm{a}$, at 420-22 (2d ed. 1998). The LRA principle had previously been applied in a mental disability law context in the statutory case of Lake v. Cameron, 364 F. 2d 657 (D.C. Cir. 1966).

${ }^{24}$ Lessard, 349 F. Supp. at 1096.

${ }^{25} I d$.

${ }^{26}$ On the issue of the patient's right to a written treatment plan, see e.g., Maxwell, 703 P.2d 
regulation of the conditions of confinement, ${ }^{27}$ the availability of treatment, ${ }^{28}$ and the right of a patient to refuse treatment. ${ }^{29}$

\section{B. The First Generation of Studies}

A major study commissioned by the National Center for State Courts listed these factors as essential in any assessment of an LRA determination:

the environmental restrictiveness of the treatment setting; the psychological or physical restrictiveness of behavioral, chemical, or biological treatment; clinical variables, including the person's behavior as it relates to the legal criteria for involuntary commitment; the relative risks and benefits of treatment alternatives; the family and community support available in the person's environment; the quality or likely effectiveness of the alternative care and treatment; the duration of treatment; the likelihood that a person may pose a risk to public safety; the availability, cost, and accessibility of alternative treatment and care; the likelihood of the person's cooperation or compliance with the conditions of alternative treatment programs; and mechanisms for monitoring and reviewing that compliance. $^{30}$

Thus, any TJ consideration of Kendra's Law — or any other contemporaneous AOT law-must be considered in the context of these factors. Expound on this, perhaps use an example or case study about why these are intrinsically related to TJ.

\section{Early OPC Laws}

Early OPC laws flowed from the application of these LRA principles in an effort to narrow-not widen-the net of those subject to involuntary civil commitment. For example, the North Carolina law- universally seen as the paradigmatic outpatient commitment statute-allowed "an examining mental health professional to recommend outpatient commitment in the case of a mentally ill

574 (Ariz. App. 1985) (order for treatment which committed patient to program of combined in-patient and out-patient treatment was void, absent showing that court was presented with and approved written treatment plan; order vacated); see also In re J.M.R., 505 A.2d 662 (Vt. 1986) (trial court could not continue involuntary treatment on non-hospitalized basis for indeterminate time, absent any finding that patient was dangerous to himself or others, or would become so if treatment plan was discontinued). But see In re Harhut, 367 N.W.2d 628 (Minn. Ct. App. 1985) (trial court erred in prescribing specific treatment programs, in ordering the county to prepare treatment reports and the hospital to submit a program plan to the court, and in ordering the county to create community placements in a commitment order).

${ }^{27}$ See, e.g., Scott v. Plante, 641 F.2d 117 (3d Cir. 1981), vacated, 458 U.S. 1101, on remand, 691 F.2d 634 (3d Cir. 1982). For a subsequent case, see Matter of James, 547 N.E.2d, 759, 761-62 (III. App. 1989) (absence of report on appropriateness and availability of alternative treatment facilities and preliminary treatment plan required commitment reversal).

${ }^{28}$ See, e.g., Romeo v. Youngberg, 644 F.2d 147 (3d Cir. 1980)(vacated, 457 U.S. 307 (1982).

${ }^{29}$ See, e.g., Rennie v. Klein, 462 F. Supp. 1131 (D.N.J. 1978), suppl., 476 F. Supp. 1294 (D.N.J. 1979), modified, 653 F.2d 836 (3d Cir. 1981), vacated, 458 U.S. 1119 (1982), on remand, 720 F.2d 266 (3d Cir. 1983).

${ }^{30}$ Ingo Keilitz et al, Least Restrictive Treatment of Involuntary Patients: Translating Concepts Into Practice, 29 ST. LouIS U. L.J. 691, 696 (1985). 
patient $^{31}$ "capable of surviving safely in the community with available supervision from family, friends, or others," 32 where the individual is "in need of treatment in order to prevent further disability or deterioration which would predictably result in dangerousness," 33 and where the patient is unable to make an informed decision "to seek voluntary treatment or comply with recommended treatment." 34

Several studies examined the actual effect of this form of commitment. ${ }^{35}$ In one study, researchers who examined all court-ordered outpatient commitments in one court for a two year period found a high success rate for the patients involved; ${ }^{36}$ fewer than $13 \%$ of patients involved were rehospitalized during the time frame, ${ }^{37}$ leading the researchers to conclude that such commitment was effective in providing treatment and control of dangerousness ${ }^{38}$ (while enabling respondents to maintain their roles and networks in familiar surroundings), ${ }^{39}$ and

${ }^{31}$ N.C. Gen. Stat. § 122C-263(d)(1)(a) (1997).

32 N.C. Gen. Stat. § 122C-263(d)(1)(b) (1997). Cf. O'Connor v. Donaldson, 422 U.S. 563 (1975).

${ }^{33}$ N.C. Gen. Stat. § 122C-263(d)(1)(c) (1997). See, e.g., Matter of Mental Condition of W.R.B., 411 N.W.2d 142, 143 (Wis. App. 1987), rev. den., 416 N.W. 2d 297 (Wis. 1987):

The clear intent of the legislature ... was to avoid the "revolving door" phenomenon whereby there must be proof of a recent overt act to extend the commitment but because the patient was still under treatment, no overt acts occurred and the patient was released only to commit a dangerous act and be recommitted. The result was a vicious circle of treatment, release, overt act, recommitment.

Statutes typically look at medication compliance as one of the criteria for invoking OPC, see, e.g., Wis. Stat. AnN. § 51.20(13)(dm) (1998), text effective until Dec. 1, 2001 (OPC permissible if court finds dangerousness of patient "is likely to be controlled with appropriate medication administered on an outpatient basis"); TenN. CoDE ANN. § 33-6-201(b)(2) (1997) (allowing OPC where patient is subject to the "obligation to participate in any medically appropriate outpatient treatment, including ... medication ..." "), and case law seems to explicitly endorse this use of OPC, see, e.g., In re Anderson, $140 \mathrm{Cal}$. Rptr. 546, 550 (App. 1977) (medication an appropriate condition of outpatient treatment). Compare In re Richardson, 481 A.2d 473, 479 n.5 (D.C. 1984) ("“n]ot every instance of the outpatient's failure to take prescribed medication or attend therapy sessions justifies the conclusion that he is not cooperating with the treatment program").

${ }^{34}$ N.C. Gen. Stat. § 122C-263(d)(1)(d) (1997).

${ }^{35}$ See Robert Miller, Commitment to Outpatient Commitment: A National Survey, 36 Hosp. \& Commun. Psychiatry 265, 266 (1985) (national survey revealed that two-thirds of the jurisdictions that permit outpatient commitment use it as an alternative to inpatient treatment in fewer than 5\% of commitments). See also Parker \& Knoll, Partial Hospitalization: An Update, 147 Ам. J. Psychiatry 156 (1990) (discussing relatively low utilization of partial hospitalization as treatment modality); Gerry McCafferty \& Jeanne Dooley, Involuntary Civil Commitment: An Update, 14 Ment. \& Phys. Dis. L. ReP. 277 (1990) (reviewing recent outpatient statutes); Ingo Keilitz, Empirical Studies and Involuntary Outpatient Commitment, 14 Ment. \& Phys. Dis. L. Rep. 368 (1990) (research studies).

${ }^{36}$ Virginia Hiday \& Rodney Goodman, The Least Restrictive Alternative to Involuntary Hospitalization, Outpatient Commitment: Its Use and Effectiveness, 10 J. Psychiatry \& L. 81 (1982).

${ }^{37} \mathrm{Id}$. at 81 .

${ }^{38} \mathrm{Id}$. at 91 .

${ }^{39} \mathrm{Id}$. 
was "not only more rational in terms of human costs, but also . . . more rational in terms of financial costs to the taxpayer." 40

On the other hand, another North Carolina survey conducted by other researchers reported that the new statute had little impact on the use of outpatient commitment, ${ }^{41}$ reporting that, while the number of cases in which hospital staff recommended outpatient treatment significantly increased after the effective date of statutory change. ${ }^{42}$ The percentage of cases studied in which outpatient commitment was ordered actually decreased slightly. ${ }^{43}$

A follow-up study by the same researchers focused on several reasons why, in their view, outpatient commitment had not become a particularly significant "therapeutic modality": 44 (a) court reluctance to employ outpatient commitment when "dangerousness" is a commitment criteria; ${ }^{45}$ (b) reluctance of community facility staff to treat unwilling patients; ${ }^{46}$ (c) lack of interest by community facility staff in outpatient commitment; ${ }^{47}$ and (d) lack of knowledge about the procedures involved. ${ }^{48}$

${ }^{40}$ Id. See Mark Munetz et al, The Effectiveness of Outpatient Civil Commitment, 46 PsYCHIATRIC SERV. 1251 (1996) (when used "judiciously," OPC "helpful tool in maintaining hospital recidivists in the community").

${ }^{41}$ Robert Miller \& Paul Fiddleman, Involuntary Civil Commitment in North Carolina: The Result of the 1979 Statutory Changes, 60 N.C. L. Rev. 985, 1013 (1982).

${ }^{42} \mathrm{Id}$. at 1010 (staff recommended outpatient commitment for $44 \%$ of committed patients who were committed to outpatient treatment prior to the law's effective date, and $77 \%$ of those committed afterward).

${ }^{43} I d$. (percentage dropped from $4.7 \%$ to $3.1 \%$ ). The authors reported further that, of the thirty-five outpatient commitment cases studied, only one satisfied all the requisite statutory provisions. Id. at 1013, and see id. at n. 118.

${ }^{44}$ Robert Miller \& Paul Fiddleman, Outpatient Commitment: Treatment in the Least Restrictive Environment?, 35 Hosp. \& Commun. Psychiatry 147, 149 (1984).

${ }^{45} \mathrm{Id}$. On the other hand, the researchers indicate that, in some circumstances, courts improperly overutilize outpatient commitment "when the judge is convinced that further treatment is advisable but feels that the legal evidence is insufficient to justify inpatient commitment," using outpatient commitment as a sort of plea bargain-compromise. Id.

${ }^{46}$ Miller \& Fiddleman, supra note 44, at 149 . The authors see this reluctance as an outgrowth of the increasing number of nonmedical personnel at such centers, see, e.g., Fink \& Weinstein, Whatever Happened to Psychiatry? The Deprofessionalization of Community Mental Health Centers, 136 Aм. J. Psychiatry 406 (1979), who are less comfortable with coerced treatment than are physicians, see Mendel \& Rapport, Determinants of the Decision for Psychiatric Hospitalization, 20 Arch. Gen. Psychiatry 321 (1969), and also "less enthusiastic about forcing patients to come for nonmedical treatment," Miller \& Fiddleman, supra note 44, at 150.

${ }^{47}$ See Virginia Hiday \& Teresa Scheid-Cook, The North Carolina Experience with Outpatient Commitment: A Critical Appraisal, 10 InT'L J.L. \& Psychiatry 215, 230 (1987) (empirical study suggests that extent of community mental health center "dedication to making [outpatient commitment] work" important variable in success of outpatient commitment status).

${ }^{48}$ Miller \& Fiddleman, supra note 44, at 150; see also, Jeffrey Geller, Clinical Guidelines for the Use of Involuntary Outpatient Treatment, 41 Hosp. \& Commun. Psychiatry 749 (1990). On this point, Miller and Fiddleman concluded:

Until these entrenched attitudes change, outpatient commitment will not become a realistic alternative to hospitalization. Despite legal sanctions, outpatient commitment is too easily sabotaged to succeed without cooperation from all parties.

Id. at 151 . 


\section{B. More Recent Studies}

The majority of the studies just referred to were done in the 1980's. What can be learned from the more recent studies? Perhaps the most interesting was one done by Randy Borum and his colleagues investigating the beliefs of persons with mental illness about the provisions and implications of outpatient commitment laws. ${ }^{49}$ Borum questions "what obligations, if any, do clinicians have to educate respondents about the actual provisions and limitations of their outpatient commitment?"50 Borum's research-a survey of over 300 North Carolina patients subject to OPC - had revealed that eighty-three percent believed incorrectly that the OPC order itself permitted the forcible administration of involuntary medications. ${ }^{51}$ To what extent must judges ensure that individuals subject to Kendra's Law understand that law's limitations on this matter?

Other studies have begun to fill in some of the gaps in the research picture. They suggest that, empirically, outpatient commitment can work to reduce hospital readmissions and total hospital days, that patients who keep postdischarge follow-up appointments had a far lower chance of being rehospitalized than those who did not keep such appointments, ${ }^{52}$ but that, to succeed, a "substantial commitment of treatment resources" is required. ${ }^{53}$ Other scholars and clinicians have recently cautioned about the "unintended negative consequences" of extending the use of coercive techniques through OPC. Leonard Stein and Ronald Diamond, for instance, note that mandatory OPC "may raise concerns among other persons with mental illness that such orders could be used against them,"

For subsequent empirical investigations of the North Carolina experience, see Virginia Hiday \& Teresa Scheid-Cook, A Follow-Up of Chronic Patients Committed to Outpatient Treatment, 40 Hosp. \& Commun. Psychiatry 52 (1989) (patients committed to outpatient treatment "significantly more likely" than either released patients or involuntarily hospitalized patients to utilize aftercare services and continue in treatment); Hiday \& Scheid-Cook, supra note 47, at 229 (of those outpatient committees who participated in treatment, outpatient status "works in terms of keeping patients in treatment and on medication, increasing compliance, permitting residence outside an institution and social interaction outside the home, and maintaining patients in the community with few dangerous episodes"); Gustavo Fernandez \& Sylvia Nygard, Impact of Involuntary Outpatient Commitment on the Revolving-Door Syndrome in North Carolina, 41 Hosp. \& Commun. Psychiatry 1001 (1990) (finding statistically significant reduction in number of "revolving door" patients); Virginia Hiday \& Teresa Scheid-Cook, Outpatient Commitment for "Revolving Door" Patients, 179 J. Nerv. \& MEnT. Dis. 83 (1991) (outpatient commitment induces compliance and leads to treatment maintenance even among "revolving door" patients); Erika King, Outpatient Civil Commitment in North Carolina: Constitutional and Policy Concerns, 58 LAw \& ConTEMP. Probs. 250 (Spring 1995).

For subsequent literature, see e.g., 1 PERLIN, supra note 6, § 2C-7.3, at 491-92 n. 1379 (citing articles).

${ }^{49}$ Randy Borum et al, Consumer Perceptions of Involuntary Outpatient Commitment, 50 PSYCHIATRIC SERV. 1489 (1999).

${ }^{50}$ Id. at 1491 .

${ }^{51} \mathrm{Id}$. at 1490 .

${ }^{52}$ E. Anne Nelson et al, Effects of Discharge Planning and Compliance with Outpatient Appointments on Readmission Rates, 51 PsychiATRIC. Serv. 885 (2000).

${ }^{53}$ Marvin Swartz et al, Can Involuntary Outpatient Commitment Reduce Hospital Recidivism? Findings from a Randomized Trial with Severely Mentally Ill Individuals, 156 AM. J. PSYCHIATRY 1968 (1999). 
thus "frightening ... potential clients away from the treatment system." ${ }^{54}$ Similarly, Michael Hoge and Elizabeth Grottole argue that, because OPC covers individuals not otherwise subject to forced medication to take such medication against their will (through reliance on the patients' mistaken belief that medications would otherwise be forced), it thus "devalues the individuals being served, and undermines the physician-patient relationship .... A strategy that relies on patient misinformation to foster its success violates ethics principles, the integrity of the physician-patient relationship, and the notion of informed consent." 5.

The question of coercion was given a different, but very troubling, spin 4 years ago at the American Psychiatric Association national conference on preKendra's outpatient commitment laws. There, Dr. Susan Stabinsky reported that "most" of the mandated patients she had observed were women "forced into treatment as a condition of getting their children back." ${ }^{56}$ At the same meeting, Dr. Kenneth Gilbert expressed his discomfort with the possibility that AOPC was being used to "serv[e] the ends" of the criminal justice system. ${ }^{57}$ It is surprising that there has been so little attention paid to this troubling data. ${ }^{58}$

Finally, commentators have begun to look at the question of funding. Stein and Diamond are clear: "without adequate funding such a law would result in no real improvement in the system." 59 Similarly, the National Association of State Mental Health Program Directors has concluded: "At a minimum, if a state decides to implement [OPC], it must allocate sufficient resources to communitybased treatment." $" 60$

\section{Forced Drugging}

There is no question that the most controversial aspect of contemporary OPC laws is the linkage between commitment and forced drugging, and it is likely that this will be the part of Kendra's Law and other recent laws that will receive the most attention (both in the press and in the academic commentaries). In a powerful — and to my mind, generally persuasive — critique from a civil libertarian perspective, Steven Schwartz and Cathy Costanzo focus on outpatient commitment as "an expression of the much enlarged authority which developed over the past century to promote the health or interests of persons considered to be mentally infirm," and characterize it as a "significant distortion of the historical

${ }^{54}$ Leonard Stein \& Ronald Diamond, Commentary: A "Systems"-Based Alternative to Mandatory Outpatient Treatment, 28 J. Am. Acad. Psychiatry \& L 159, 159 (2000).

${ }_{55}$ Michael Hoge \& Elizabeth Grottole, The Case Against Outpatient Commitment, 28 J. Ам. ACAD. Psychiatry \& L. 165, 167 (2000).

${ }^{56}$ Psychiatrists Divided Over Usefulness of Outpatient Commitment, Psychiatric News (Sept. $4,1998)$, at 12 .

${ }^{57} \mathrm{Id}$. at 18 .

${ }^{58}$ I address this lack of attention in Michael L. Perlin, "“On Desolation Row': The Blurring of The Borders Between Civil and Criminal Mental Disability Law, and What it Means to All of Us," keynote address, first International Conference on Forensic Mental Health Services, Vancouver, BC, Canada, April 2001.

${ }^{59}$ Stein \& Diamond, supra note 54, at 160.

${ }^{60}$ Technical Report, supra note 12, at 15 (emphasis added). 
purposes and benign motivation of the parens patriae principle," ${ }^{, 61}$ and, primarily, as a "guise for substantially modifying the criteria for state-imposed psychiatric intervention." ${ }^{2}$ Additionally, Professor Susan Stefan has "unpacked" outpatient commitment to differentiate "traditional" outpatient commitments (premised on least restrictive alternative constructs and conditional release schemata) from the post-deinstitutionalization model which she characterizes as "preventive commitment" (PC) ${ }^{63}$ According to Stefan, by focusing on the specter of deterioration, an implied presumption of incompetency, and an assumed availability of treatment, ${ }^{64}$ PC "broadens the class of people subject to commitment, and expands the conditions under which the state can intervene in a person's life." ${ }^{\prime 65}$

Both Stefan and Schwartz/Costanzo focus sharp criticism on precisely the issue which is frequently seen as the linchpin of outpatient commitment's efficiency value: its use as a tool to compel medication compliance in the community ${ }^{66}$ Stefan characterizes forced medication as the "core of outpatient commitment;" ${ }^{67}$ Schwartz and Costanzo speculate that outpatient commitment "already has or will become synonymous with forced medications." 68 This takes on greater importance in the context of recent literature that charges that community mental health services have never been truly accessible to former state hospital patients, ${ }^{69}$ and of case law that holds that Community Mental Health Centers (CMHCs) have

${ }^{61}$ Steven Schwartz \& Cathy Costanzo, Compelling Treatment in the Community: Distorted Doctrine and Violated Values, 20 Loy. L.A. L. REv. 1329, 1346-48 (1987).

${ }^{62} \mathrm{Id}$. at 1404.

${ }^{63}$ Susan Stefan, Preventive Commitment: The Concept and Its Pitfalls, 11 Ment. \& Phys. Dis. L. REP. 288 (1987).

${ }^{64}$ Id. at $288-91$.

${ }^{65} \mathrm{Id}$. at 296.

${ }^{66}$ Schwartz \& Costanzo, supra note 61, at 1384 ("Thus, the issue is not competency but preference: when a person chooses not to take the drugs which a psychiatrist deems necessary, and some form of psychological deterioration is predicted to follow, coercion is considered desirable") (footnote omitted). See also id. at 1383 n.245, quoting, in part, Miller \& Fiddleman, supra note 44, at 149:

Pychiatrists forthrightly acknowledge that the most convincing clinical rationale for involuntary community care is to force resistant patients to take their drugs. Clinicians argue that outpatient commitment is ideal for a patient who can be maintained in remission with medication but who does not take it voluntarily or consistently. They contend that continued court supervision is justified by the patient's history of repeated psychotic episodes when medication is discontinued.

Compare 1 PerLin, supra note 6, § 2B-5.2 (2d ed. 1998).

${ }^{67}$ Stefan, supra note 63, at 294. See also John La Fond, The Homeless Mentally Ill: Is Coercive Psychiatry the Answer? (paper presented at annual meeting of American Association of Law Schools, January 1990, San Francisco, CA), manuscript at 10 (in outpatient settings, "[d]rugs-with all their risks-will undoubtedly be the treatment of choice"). See generally for an analysis in one jurisdiction, Elizabeth Furlong, Coercion in the Community: The Application of Rogers Guardianship to Outpatient Commitment, 21 N. Eng. J. Civ. \& CRIM. Confinement 485 (1995).

${ }^{68}$ Schwartz \& Costanzo, supra note 61, at 1368. See, e.g., In re K.B., 562 N.W. 2 d 208 (Mich. App. 1997) (outpatient returned to involuntary hospitalization status after she refused to take antipsychotic medication).

69 See E. Fuller Torrey, Nowhere to Go: The Tragic Odyssey of the Homeless Mentally ILL 138-60 (1988). 
the right to refuse admission to state hospital outpatients. ${ }^{70}$ If OPC's success depends on the dedication of CMHCs to "making [it] work," the concern that such facilities may pay only "lip service" to the status may force a reconsideration of $\mathrm{OPC}$ as a tool by which to enforce community drugging. ${ }^{71}$

One of the implicit "givens" of the contemporary OPC debate is that persons with mental illness are not competent-in a lay sense, if not in a legal sense-to decide whether to self-medicate in a community setting. ${ }^{72}$ And this assumption has rarely been challenged. ${ }^{73}$ But, important conceptual light has been shed on this entire murky area of the law by the publication of research by the MacArthur Foundation's Network on Mental Health and the Law (the "Network"). ${ }^{74}$ For the past decade, the Network has conducted an extensive study of three areas that are essential to an informed understanding of mental disability law: competence, coercion, and risk. ${ }^{75}$ The competence aspect of the research ${ }^{76}$ reports on the researchers' attempts to develop a reliable and valid information base upon which to address clinical and policy questions about mentally disabled persons' ability to provide informed consent to treatment. ${ }^{77}$

Among the Network's findings of significance to the question that I address in this article are the conclusions that mental patients are not always incompetent

\footnotetext{
${ }^{70}$ Rhode Island Dep't of Mental Health v. R.B., 549 A.2d 1028, 1031 (R.I. 1988).

${ }^{71}$ Hiday \& Scheid-Cook, supra note 47, at 230-31. See generally Michael L. Perlin, Reading the Supreme Court's Tea Leaves: Predicting Judicial Behavior in Civil and Criminal Right to Refuse Treatment Cases, 12 Am. J. Forens. Psychiatry 37, 50-51 (1991). On the relationship between CMHCs and outpatient systems, see Wilk, Implications of Involuntary Outpatient Commitment for Community Mental Health Agencies, 58 AM. J. ORThOPSychiatry 580 (1988).

72 See 1 Perlin, supra note 6, \$2C-7.3, at 497-98; Perlin, supra note 20, at 1049.

${ }^{73}$ See, e.g., Michael L. Perlin \& Deborah A. Dorfman, Is It More Than "Dodging Lions and Wastin' Time”? Adequacy of Counsel, Questions of Competence, and the Judicial Process in Individual Right To Refuse Treatment Cases, 2 Psychol., Pub. PoL'y \& L. 114, 133-34 (1996):

Judges regularly decide involuntary civil commitment cases not under the terms of the underlying statutes, but rather on the basis of their perceptions of whether patients will self-medicate in the community.

See also, Perlin, supra note 71, at 52-59; Theresa Scheid-Cook, Commitment of the Mentally Ill to Outpatient Treatment, 23 Community Mental Health J. 173, 180-81 (1987).

${ }^{74}$ Michael L. Perlin, "Make Promises by the Hour": Sex, Drugs, the ADA, and Psychiatric Hospitalization, 46 DePAul L. Rev. 947, 973 (1997).

${ }^{75}$ Bruce J. Winick, Foreword: A Summary of the MacArthur Treatment Competence Study and an Introduction to the Special Theme, 2 Psychol, Pub. Pol'y \& L. 3, 3 (1996). See also, e.g., Thomas Grisso \& Paul Appelbaum, Values and Limits of the MacArthur Treatment Competence Study, 2 Psychol., Pub. Pol'y \& L. 167 (1996); Ronald Roesch, Stephen D. Hart, Patricia A. Zapf, Conceptualizing and Assessing Competency to Stand Trial: Implications And Applications of the MacArthur Treatment Competence Model, 2 Psychol. Pub. PoL'y \& L. 96 (1996); Susan Stefan, Race, Competence Testing, and Disability Law: A Review of the MacArthur Competence Research, 2 Psychol., Pub. Pol'y \& L. 31 (1996).

${ }^{76}$ See, e.g., Paul S. Appelbaum \& Thomas Grisso, The MacArthur Treatment Competence Study. I: Mental Illness and Competence To Consent to Treatment, 19 Law \& Hum. Behav. 105 (1995); Thomas Grisso et al., The MacArthur Treatment Competence Study. II: Measures of Abilities Related to Competence To Consent to Treatment, 19 LAW \& Hum. Behav. 127 (1995); Thomas Grisso \& Paul S. Appelbaum, The MacArthur Treatment Competence Study. III: Abilities of Patients To Consent to Psychiatric and Medical Treatments, 19 Law \& Hum. Behav. 149 (1995).

${ }^{77}$ Winick, supra note 75 at 3 .
} 
to make rational decisions and that mental patients are not inherently more incompetent than nonmentally ill patients. ${ }^{78}$ In fact, on "any given measure of decisional abilities, the majority of patients with schizophrenia did not perform more poorly than other patients and nonpatients." 79 In short, the presumption in which courts have regularly engaged - that there is both a de facto and de jure presumption of incompetency to be applied to medication decision making ${ }^{80}$ appears to be based on an empirical fallacy: psychiatric patients are not necessarily more incompetent than nonmentally ill persons to engage in independent medication decision making.

If this is so, then it appears that the Stefan/Schwartz \& Costanzo critique is largely accurate, and that statutes that suggest a de facto presumption of incompetency are not merely likely unconstitutional, but are also based on a critical misreading of the empirical data.

\section{Kendra's Law}

With this as backdrop, I will turn my attention to Kendra's Law, ${ }^{81}$ and first, consider briefly the legislative findings. ${ }^{82}$ The legislature makes clear its intent in passing this act:

The legislature finds that there are mentally ill persons who are capable of living in the community with the help of family, friends and mental health professionals, but who, without routine care and treatment, may relapse and become violent or suicidal, or require hospitalization. The legislature further finds that there are mentally ill persons who can function well and safely in the community with supervision and treatment, but who without such assistance, will relapse and require long periods of hospitalization. ${ }^{83}$

Under Kendra's Law, a court may order a person to submit to assisted outpatient treatment if the court finds that the patient

- is at least 18 years of age, and;

- suffers from a mental illness; and,

- is unlikely to survive safely in the community without supervision, as deemed by a clinical determination; and, has a history of noncompliance with treatments that has resulted in one or more seriously violent acts, threats of violence or attempted violence, toward self or others within the last 48 months, or which has resulted in a hospitalization or receipt of mental health services at a correctional facility at least twice within the last 36 months-excluding the period of hospitalization or incarceration immediately prior to the filing of the petition; and,

${ }^{78}$ Perlin \& Dorfman, supra note 73, at 120 (discussing research in Grisso \& Appelbaum, supra note 75$)$

${ }^{79}$ Grisso \& Appelbaum, supra note 76, at 169.

${ }^{80}$ On this presumption in general, see Bruce J. Winick, The MacArthur Treatment Competence Study: Legal and Therapeutic Implications, 2 Psychol., PuB. PoL'y \& L. 137 (1996).

${ }^{81}$ Kendra's Law was originally enacted as 1999 NY S.B. 5762.

${ }^{82}$ Perlin, supra note 74 , at $948-50$.

831999 NY S.B. 5762, § 2. 
- is unlikely to voluntarily participate in treatment; and,

- will likely benefit from treatment and needs such treatment in order to prevent behavior likely to result in serious harm to the patient or others. ${ }^{84}$

Court proceedings are initiated by petitions. Potential petitioners include parents, spouses, persons with whom the subject resides, children, siblings, a qualified treating psychiatrist, or a probation or parole officer charged with supervising the individual. ${ }^{85}$ The petition must be accompanied by an affidavit of a physician - not the petitioner - who attests either that he or she has examined the patient within 10 days and recommends assisted outpatient treatment, or that the physician has been unable to examine the patient because of non-cooperation by the patient and that "such physician has reason to suspect that the subject of the petition meets the criteria for assisted outpatient treatment . .."86

The statute provides for a hearing on notice to the patient/respondent who is entitled to counsel ${ }^{87}$ at which the physician submitting the affidavit must testify, ${ }^{88}$ present a treatment plan, and establish that it is the "least restrictive" alternative available. ${ }^{89}$ The court may also order an involuntary examination of the respondent. $^{90}$

After the hearing, the court may order the subject of the petition to receive assisted outpatient treatment for an initial period of no greater than six months. ${ }^{91}$ Before issuing this order, however, the court must find that the clear and convincing evidence establishes that the subject meets the criteria for assisted outpatient treatment and that there is no appropriate or feasiblely less restrictive alternative. $^{92}$

Again, the most controversial aspect of Kendra's Law deals with enforced medication. The court's order may also require the patient to self-administer psychotropic drugs or accept the administration of such drugs by authorized personnel as part of an assisted outpatient treatment program, ${ }^{93}$ but may not order treatment that has not been recommended by the examining physician and included in the written treatment plan. ${ }^{94}$ Such treatment may be ordered for periods of up to 1 year. $^{95}$

One issue that has arisen in other OPC jurisdictions is the availability of contempt as a remedy for noncompliant patients. For instance, in two Indiana cases, outpatients were held by trial courts to be in criminal contempt for failing to adhere to medication regimens. In one, the appellate court found that the trial

\footnotetext{
${ }^{84}$ N.Y. MENT. Hyg. L. $§ 9.60$ (C).

${ }^{85}$ N.Y. MENT. Hyg. L. $\$ 9.60$ (E)(1) (I-VII).

${ }^{86}$ N.Y. MENT. HYG. L. $\$ 9.60$ (E) (3) (II).

${ }^{87}$ N.Y. Ment. Hyg. L. $\$ 9.60(\mathrm{G}),(\mathrm{H})(1)$.

${ }^{88}$ N.Y. MENT. Hyg. L. $\$ 9.60(\mathrm{H})(2)$.

${ }^{89}$ N.Y. MENT. Hyg. L. $§ 9.60(\mathrm{H})(4)$.

${ }^{90}$ N.Y. MENT. HYG . L. $\$ 9.60(\mathrm{H})(3)$

${ }^{91}$ N.Y. Ment. Hyg. L. § 9.60 (J) (2).

${ }^{92} I d$.

93 N.Y. Ment. Hyg. L. $\$ 9.60$ (J) (4).

94 N.Y. MENT. HyG. L. § 9.60 (J) (1)-(4).

95 N.Y. Ment. Hyg. L. § 9.60 (K).
} 
court erred in so doing without determining whether the patient's conduct was "willful [or] a manifestation of mental illness." 96 In the other, after an intermediate appellate court affirmed the lower court's finding where patient's counsel expressly stated that the refusal was "willful and voluntary,"97 the state supreme court reversed, holding that the trial court had no authority either to order the patient to take medication as an outpatient or to hold him in contempt for refusing to do so. ${ }^{98}$

But under Kendra's Law, a patient who fails or refuses to comply with a treatment plan authorized by the court cannot be held in contempt of court. ${ }^{99}$ The only recourse available is if a physician finds such person to be in need of involuntary admission to a hospital, pursuant to Mental HyG. L. $§ 9.27$, or in need of "immediate observation, care and treatment pursuant" to $\S 9.39$ or $\S 9.40 .^{100}$ Such an individual can be transported to a hospital and held up to 72 hr to determine if he or she is in need of "involuntary care and treatment."101 The statute specifically provides, however, that "an order of assisted outpatient treatment shall not be grounds for involuntary civil commitment . . ."102

\section{Unanswered Questions}

What questions are left unanswered by this law? There are many, but I believe that this is a helpful sample of those that require clarification and/or resolution:

1. Its relationship to other New York law: What is the relationship between Kendra's Law and other New York OPC legislation, specifically the Bellevue pilot program authorized by Mental Hygiene Law $§ 9.61 ?^{103}$ An exhaustive study of the Bellevue program found little outcome difference between individuals who participated in that program and a control group (although the authors of the study noted that several contextual factors, including sample size and lack of enforcement mechanisms, "constrain the conclusions that can be drawn from these data"); ${ }^{104}$ how significant are these results to a Kendra's law analysis?

2. The implications of "widening the net": What are the implications of "widening the universe of persons who are potentially subject to commitment, the state must then take on the added burden of creating a

${ }^{96}$ Matter of Utley, 565 N.E.2d 1152, 1156-57 (Ind. Ct. App. 1991) (affirming judgment because patient did not attack underlying commitment order).

${ }^{97}$ Matter of Tarpley, 566 N.E.2d 71, 77 (Ind. Ct. App. 1991), compare id. at 77, 78 (Sullivan, J., dissenting) (counsel's concession does not "exclude the very real possibility, if not probability, that the refusal was induced by Tarpley's severe delusions and withdrawal from reality").

${ }^{98}$ Matter of Tarpley, 581 N.E.2d 1251, 1252 (Ind. 1991), reh'g denied (1992).

${ }^{99}$ N.Y. Ment. Hyg. L. $§ 9.60(\mathrm{~N})$.

${ }^{100} \mathrm{Id}$.

${ }^{101} I d$.

${ }^{102} I d$.

${ }^{103}$ N.Y. MENT. HYG. L. $\$ 9.61$.

${ }^{104}$ Henry Steadman et al, Assessing the New York City Involuntary Outpatient Commitment Pilot Program, 52 Psychiatric Serv. 330, 335 (2001). 
system which is capable of absorbing the additional committees"? ${ }^{105}$ Although this means providing extra funds for extra lawyers, mental health professionals and expert witnesses, the proposed legislation has no funding provisions for such system participants. Section 47.03 of the Mental Hygiene Law was amended to authorize the commissioner of mental health to make grants to provide medication to persons subject to Kendra's Law ${ }^{106}$ and to develop plans by which medications can be prescribed and administered, ${ }^{107}$ but these grants are apparently to come from existing funds, as the law specifies "within amounts appropriated therefore." 108

3. Time period allocations: How significant is the short amount of time (3 days) which counsel is given to prepare cases. ${ }^{109}$ The problems here may be exacerbated because the persons subject to Kendra hearings are not yet in a hospital setting at the time the petition is filed, and thus are "much harder to track down," 110 leading to the possibility that vigorous advocacy - always a problem in cases involving persons with serious mental disabilities-may be impossible. ${ }^{111}$ Interestingly, Dr. Howard Telson-a clinical assistant professor of psychiatry at New York University - concurred, saying that the Kendra's Law petition and hearing process will be more "cumbersome" because it deals with individuals outside the hospital system. ${ }^{112}$

4. The state's track record: How relevant is the state's shaky track record in the creation of outpatient facilities and services? ${ }^{113}$ John Gresham, senior litigation counsel at Lawyers for the Public Interest, has said that the petitions "were an imperfect way to help patients, and that petition filings and court hearings may divert funds and attention away from hospitals." 114 Again, the National Association of State Mental Health Program Directors has concluded: "It is clear that [OPC] will not accomplish its objectives without a strong community-based service provision system."115

5. Implications of hearings in absentia: What are the logistical problems that flow from the trial court's ability to hold the hearing in the subject's

${ }^{105}$ Keri Gould, Is Kendra's Law the Answer? No, 222. N.Y.L.J. (May 19, 1999), at 2.

${ }^{106} 1999$ N.Y.S.B. 5762, § 15(a).

${ }^{107} I d$., $§ 15$ (b), (c).

${ }^{108} I d$., \& 15(a).

109 Yael Schacher, Courts, Lawyers Are Gearing Up to Handle Kendra's Law Hearings, 222

N.Y.L.J. (Sept. 30, 1999), at 1.

110 Id. at 6 .

${ }^{111}$ See e.g, Michael L. Perlin, Fatal Assumption: A Critical Evaluation of the Role of Counsel in Mental Disability Cases, 16 Law \& Hum. Behav. 39 (1992)

${ }^{112}$ Schacher, supra note 109 , at 1 .

${ }^{113} I d$.

${ }^{114} \mathrm{Id}$.

${ }^{115}$ Technical Report, supra note 12, at 15 (emphasis added). 
absence if "the subject of the petition does not appear at the hearing, and appropriate attempts to elicit the attendance of the subject have failed, the court may conduct the hearing in such subject's absence"? ${ }^{16}$ If the subject is homeless, and thus is not susceptible to service, of what value could such a hearing in absentia have?

6. Relationship to the Americans with Disabilities Act: What are the implications of the Americans with Disabilities Act and the Supreme Court's 1999 decision in Olmstead v. L.C., ${ }^{117}$ qualifiedly affirming a lower court decision finding a right to community treatment for certain state hospital patients? ${ }^{118}$

7. "Blurring" of borderlines. What "blurring" issues are raised when a forensic facility becomes the "Kendra's locus"? ${ }^{19}$ In a recent oral presentation, I focused on this "blur," 120 and I believe it is an issue in need of far more attention by all participants in the mental disability law system. What expertise, for instance, do parole officers have in linking up inpatient treatment failure to medication noncompliance? In fact,

${ }^{116}$ N.Y. Ment. Hyg. L. $§ 9.60$ (H) (1).

117527 U.S. 581 (1999).

${ }^{118}$ See Perlin, supra note 4; see also, Michael L. Perlin, "I Ain't Gonna Work on Maggie's Farm No More": Institutional Segregation, Community Treatment, the ADA, and the Promise of Olmstead v. L.C., 17 T.M. Cooley L. Rev. 53 (2000); Perlin supra note 1; Michael L. Perlin, "Their Promises of Paradise": Will Olmstead v. L.C. Resuscitate the Constitional "Least Restrictive Alternative” Principle in Mental Disability Law?, 37 Houston L. Rev. 999 (2000).

${ }^{119}$ See Perlin, supra note 58.

For several months, the AOPC Office in Steuben County was housed in the county jail. The Monroe County (Rochester) Office shares space with the county Social/Legal Clinic, responsible for the processing of incompetency to stand trial evaluations. Personal communication with David Putney, manager, Assisted Outpatient Treatment Office, Rochester, NY (March 5, 2001). For several months, the Erie County (Buffalo) Office was housed in the Erie County Jail. Personal communication with Glen Liebman, NY State Office of Mental Health, Albany, NY (March 6, 2001).

${ }^{120}$ See Perlin, supra note 58, at 5-6 (footnotes omitted):

The proliferation of so-called assisted outpatient commitment (AOPC) statutes-of which New York's Kendra's Law is the most well-known example-and of sexually violent predator acts (SVPA) - of which New Jersey's Megan's Law is often seen as the exemplar but which has been subject to Supreme Court scrutiny elsewhere in the cases of Kansas $v$. Hendricks and the Washington case of Seling v. Young-have blurred the borderline between civil and criminal mental disability law in some very troubling and problematic ways, and threaten to make this are of the law even more pretextual than it currently is. Laws such as these enforce social control in punitive ways under the guise of the beneficence of civil commitment. Although the universes of individuals subject to statutes such as Kendra's Law and Megan's Law appear quite different-in the first instance, persons not subject to the inpatient involuntary civil commitment power but who may be in danger of deterioration in the absence of forced treatment; in the second, persons who have been charged and/or convicted of violent sexual offenses who are targeted as potentially recidivistic pedophilesthere are important, and troubling, points in common in the structures of these two kinds of laws. Moreover, they both demonstrate comfort with a system in which many functions of civil and criminal mental disability law merge. Remarkably, no one, until now, has commented on this phenomenon. 
how can this link be "proven" in any case? And to what extent is this connected to the "blur" issue?

8. Role of other "players": Are there sufficient "authorized personnel"121 in New York's many sparsely-populated, rural counties to assure that ordered medication is administered? Say a patient resists assisted outpatient treatment because of a prior negative reaction to antipsychotic medication or a fear of permanent and irreversible side effects (a fear which has led the United States Supreme Court to conclude that the Fourteenth Amendment's liberty clause is implicated in drug side-effect cases). ${ }^{122}$ What will the outcome of such hearings be? And suppose that a patient asks for an independent psychiatric expert. Kendra's Law provides a right to counsel ${ }^{123}$ but there is no right to an independent expert. In Goetz v. Crosson, ${ }^{124}$ the Second Circuit held that the due process clause did not require the appointment of a psychiatrist in every involuntary civil commitment case, ${ }^{125}$ but added:

Some proceedings may present a need for independent psychiatric testimony in addition to that offered by the state to ensure an accurate decision. As a practical matter such proceedings are limited to cases in which the presiding judge determines that the record leaves unexplored or unanswered questions and that additional psychiatric testimony is necessary. In such cases, the individual's interests in both freedom and self-protection are directly affected, and the failure to provide such testimony may implicate due process concerns. ${ }^{126}$

Are Kendra's Law cases such cases? Might some Kendra's Law cases be such cases? And, if they are, who will pay the bills?

9. Liability issues: What are the liability implications if a county fails to pursue a Kendra's Law order? How, in general, are tort liability issuesespecially Tarasoff issues ${ }^{127}$ — to be resolved in Kendra's Law cases?

10. Those potentially covered by Kendra's Law: What about a prisoner who had been convicted on a count of mail fraud or state tax evasion who is

${ }^{121}$ See N.Y. Ment. Hyg. L. § 9.60(I)(1).

${ }^{122}$ See Washington $v$. Harper, 494 U.S. 210, 229-30 (1990); Riggins v. Nevada, 504 U.S. 127, 134 (1992). See also infra accompanying notes 130-138.

${ }^{123}$ N.Y. Ment. HYG. L. $\$ 9.60(\mathrm{G})$.

124967 F. 2d 29 (2d Cir. 1992).

${ }^{125} \mathrm{Id}$. at 34 .

${ }^{126} I d$.

${ }^{127}$ Tarasoff v. Board of Regents of University of California, 131 Cal. Rptr. 14 (1976) (“duty to protect"). 
prescribed Xanax while in a prison setting $?^{128}$ Does he qualify as a potential Kendra patient? Should he?

11. Financial allocation issues: How will the counties and the state sort out the difficult and important issues of "who pays what"? This latter question has been the topic of at least one court decision ${ }^{129}$ but final disposition of this issue is far from resolved.

12. Right to refuse medication issues: Then, finally, there are the constitutional issues, specifically those around the question of forced treatment. This is what the new law says:

A physician who testifies [in an outpatient commitment hearing] shall state the facts which support the allegation that the subject meets each of the criteria for assisted outpatient treatment, and the treatment is the least restrictive alternative, the recommended assisted outpatient treatment, and the rationale for the recommended assisted outpatient treatment. If the recommended assisted outpatient treatment includes medication, such physician's testimony shall describe the types or classes of medication which should be authorized, shall describe the beneficial and detrimental physical and mental effects of such medication, and shall recommend whether such medication should be selfadministered or administered by authorized personnel. ${ }^{130}$

To what extent can this be rationalized with the New York Court of Appeals decision in Rivers $v$. Katz, ${ }^{131}$ articulating the broadest right-to-refuse-treatment decision in any American jurisdiction (premised exclusively on state common and constitutional law). Rivers ordered-in most cases ${ }^{132}$ - a counseled, due process decision with respect to proposed treatment before the drugs may be administered pursuant to the State's parens patriae power."133 The court restated the "firmly

${ }^{128}$ I ask my Mental Health Law students to assume that Tony Soprano is serving time in a New York prison at a time when he is still under Dr. Melfi's care, and continues to take his prescribed Prozac. He finishes the prescribed drugs, and asks the hospital physician to renew his prescription. Does this qualify him as a potential Kendra's Law patient? The debate on this is always lively ...

129 See infra note 150.

${ }^{130}$ N.Y. MENT. Hyg. L. § $9.60(\mathrm{H})(4)$.

131504 N.Y.S. 2d 74 (1986).

${ }^{132}$ Where a patient presents a danger to self or others or "engages in dangerous or potentially dangerous conduct within the institution," the state may be warranted, under police power grounds, in administering antipsychotic medication over the patient's objections. Id., 504 N.Y.S.2d at 80. "The most obvious example of this is an emergency situation, such as when there is imminent danger to a patient or others in the immediate vicinity." Id. (citation omitted).

${ }^{133}$ Id. at 78. The court added that these principles were also recognized by the state legislature, citing to N.Y. Pub. Health Law $\$ 2504$ \& 2805-d; N.Y. Civ. Prac. L. \& R. \$4401-a, and 10 N.Y.C.R.R. §405.25(a)(7).

The cited sections provide for informed consent of adult individuals in situations involving "medical, dental, health and hospital services," N.Y. Pub. Health Law § 2504(I) (1985); set out the elements of and defenses to a medical malpractice claim based on an alleged lack of 
established" and "faithfully adhered to" common-law principles ${ }^{134}$ that "every individual of adult years and sound mind has a right to determine what shall be done with his body","135 and to control the course of his medical treatment. ${ }^{136}$ In the case of competent patients, this "fundamental" right-coextensive with the patient's liberty interest protected by the state constitution's due process clause ${ }^{137}$ _must be honored "even though the recommended treatment may be beneficial or even necessary to preserve the patient's life."138

How can the breadth of the Rivers case be reconciled with the forced treatment aspects of Kendra's Law? This is something that will and must be addressed (since, left unresolved, it would result in the anomalous situation of in-patients having many more rights than out-patients) in the coming years. Although Kendra's Law has withstood its first Rivers challenge at a trial court level in the recent case of Matter of Urcuyo, ${ }^{139}$ this is far from a settled issue. Involuntary commitment is not proof of incapacity to make such treatment decisions, ${ }^{140}$ and Kendra's Law states that a determination of commitability for outpatient treatment "shall not be construed as or deemed to be a determination that such patient is incapacitated...."141 Asks Professor Keri Gould, one of Kendra's Law's most important critics: "How then, can a court order for involuntary medication be enforced against a competent outpatient committee without an explicit constitutional violation?" 142

As a result, we are forced to consider the overarching anomaly in all

informed consent, $i d$. $\$ 2805-\mathrm{d}(1)-(4)$; set the standard upon which to assess a motion for judgment at the end of plaintiff's case in such an action, N.Y. CIV. PRAC. L. \& R. \$4401-a (1987); and mandate that hospitals establish written policies affording patients the right to "refuse treatment to the extent permitted by law and to be informed of the medical consequences of [their] action," 10 N.Y.C.R.R. \$405.25(a)(7) (1986).

${ }^{134}$ Rivers, 504 N.Y.S. 2d at 78.

${ }^{135}$ Id., quoting, in part, Schloendorff $v$. Society of New York Hosp., 105 N.E. 92, 93 (N.Y. 1914) (Cardozo, J.).

${ }^{136}$ Rivers, 504 N.Y.S.2d at 78, citing, inter alia, Matter of Storar, 438 N.Y.S.2d 266 (1981), cert. denied, 454 U.S. 858 (1981); Schloendorff, supra. Storar was a so-called "right-to-die" case, holding that where an elderly patient, prior to becoming incompetent, had consistently expressed his wish not to have his life prolonged by medical means if there were no hope for recovery, it was proper for the court to approve discontinuance of a respirator on which he was being maintained in a permanent vegetative state.

${ }^{137}$ Rivers, 504 N.Y.S.2d at 78. See Cooper v. Morin, 424 N.Y.S.2d 168, 175 (N.Y. 1979), cert. denied sub nom. Lombard v. Cooper, 446 U.S. 984 (1980) (applying due process clause of state constitution to question of adequacy of jail conditions; $c f$. Bell v. Wolfish, 441 U.S. 520 (1979)).

${ }^{138}$ Rivers, 504 N.Y.S.2d at 78, citing Storar, 438 N.Y.S.2d at 273:

Added the Court: In our system of a free government, where notions of individual autonomy and free choice are cherished, it is the individual who must have the final say in respect to decisions regarding his medical treatment in order to insure that the greatest possible protection is accorded his autonomy and freedom from unwanted interference with the furtherance of his own desires .... This right extends equally to mentally ill persons who are not to be treated as persons of lesser status or dignity because of their illness.

504 N.Y.S.2d at 78.

139714 N.Y.S. 2d 862 (Sup. Ct. 2000).

${ }^{140}$ Rivers, 504 N.Y.S. 2d at 78-79.

141 N.Y. Mental Hyg. L. $\$ 9.60$ (O).

142 Gould, supra note 105, at 2. 
involuntary civil commitment law - that while only a handful of reported involuntary civil commitment cases have ever frontally considered right to refuse treatment claims, courts routinely weigh experts' predictions of a patient's potential refusal to take antipsychotic medication in a community setting as the most probative evidence on the question of whether involuntary civil commitment is warranted, even in jurisdictions that have broad right-to-refuse decisions in place. ${ }^{143}$ What if a person subject to Kendra's Law had been successful in a Rivers action while an inpatient? ${ }^{144}$ Would that be admissible in a determination of whether such a person is likely to fail to comply with assisted outpatient treatment? ${ }^{145}$

In short, there is a host of difficult questions-policy questions, financial questions, legal questions, treatment questions, political questions- that we have not addressed through the courts or other institutions. Until these questions are seriously and thoughtfully considered, we will not be able to resolve important core Kendra's Law issues.

\section{First Cases}

Since Kendra's Law was enacted, a handful of cases have touched on its scope. ${ }^{146}$ The most important of these is Matter of Urcuyo. ${ }^{147}$ The trial court in Urcuyo upheld Kendra's Law against a Rivers-based challenge, because Kendra's Law did not "require the forcible administration of medication," 148 and similarly rejected an equal protection challenge, reasoning that "that the different treatment for assisted outpatient subjects as opposed to [alleged incapacitated persons] and involuntarily committed psychiatric patients is warranted."149 Justice Cutrona concluded:

${ }^{143}$ Michael L. Perlin, Pretexts and Mental Disability Law: The Case of Competency, $47 \mathrm{U}$. Miami L. Rev. 625, 628 (1993).

${ }^{144}$ See e.g., 2 Perlin, supra note 6, § 3B-7.2b, at 274-75 nn. 926-27 (2d ed. 1999) (citing Rivers cases).

${ }_{145}$ Compare N.Y. Ment. Hyg. L. § 9.60(N).

${ }^{146}$ For the first appellate cases decided under this law, see Application of Manhattan Psychiatric Center, 728 N.Y.S. 2d 37 (A.D. 2001) (question for the court hearing petition for assisted outpatient treatment not whether the patient should be released, but whether he should be released with or without an outpatient order; hospital must show that patient cannot be left to his own devices and must be assisted in obtaining outpatient treatment after release), discussed in Anderson, Kendra's Law Restricts Judge, N.Y.L.J. (July 27, 2001), at A1, and Matter of South Beach Psychiatric Center, 727 N.Y.S. 2d 149 (A.D. 2001) (statutory provision requiring that patient have a history of lack of compliance with treatment for mental illness that has at least twice within the last 36 months been a significant factor in necessitating hospitalization excludes the time-period during which a person was hospitalized immediately preceding the filing of the petition for assisted outpatient treatment).

For recent scholarly commentaries, see e.g., Ilissa Watnik, A Constitutional Analysis of Kendra's Law: New York's Solution for Treatment of the Chronically Mentally Ill, 149 U. PA. L. Rev. 1181 (2001); Jennifer Gutterman, Waging a War on Drugs: Administering a Lethal Dose to Kendra's Law, 68 FordHAm L. Rev. 2401 (2000).

147714 N.Y.S. 2d 862 (Supreme Ct., Nassau Cty. 2000).

${ }^{148} \mathrm{Id}$. at 868.

${ }^{149} \mathrm{Id}$. at 873 . 
Clearly, the state has a compelling interest in taking measures to prevent these patients who pose such a high risk from becoming a danger to the community and themselves. Kendra's Law provides the means by which society does not have to sit idly by and watch the cycle of decompensation, dangerousness and hospitalization continually repeat itself. Moreover, as previously discussed, Kendra's Law is narrowly tailored to achieve these goals within the framework of the involuntary and emergency commitment procedures of the Mental Hygiene Law.

In conclusion, for all of the foregoing reasons, respondents' motion for a declaration that Mental Hygiene Law 9.60 is unconstitutional absent a requirement that a respondent lacks the capacity to make a reasoned treatment decision before an Assisted Outpatient Treatment order can be granted, is denied. ${ }^{150}$

Only one other reported case has discussed medication issues in a Kendra's law context, albeit in dicta. There, in In re Conticchio, ${ }^{151}$ a guardianship application, the court sought to reconcile Kendra's Law and the Rivers decision in this way:

The recently passed legislation known as Kendra's law ... is based on the dangers that can arise from schizophrenics and other mentally disturbed persons who cease or refuse to take their necessary medication. While said law is apparently based more on the State's police power (see Rivers ... .), it reemphasizes the importance of not permitting interruptions in the treatment of such individuals. ${ }^{152}$

${ }^{150}$ Id.

In addition to Urcuyo, a few other cases also provide a window into the attitudes of the trial judges to whom Kendra's Law dockets have been assigned. In Matter of Arden Hill Hospital, the court held that the county was responsible for costs of the patient's outpatient mental health services that were not covered by Medicaid or insurance. 703 N.Y.S. 2d 902 (Orange Cty. 2000) In relatively strong language, the trial judge (Justice Bivona) read the law as reflecting a legislative finding that "even if a hospital operates an outpatient treatment program that this does not absolve the director of community services' responsibility for operation of such a program," $i d$. at 905, flatly rejecting the county's arguments that the hospital should bear the responsibility for any costs, and finding it to be "solely" the county director of community services to be responsible for provision of services, id. at 906.

In other cases, courts have variously found that a patient could be ordered to be evaluated by a physician without a prior hearing, Matter of Longo, 715 N.Y.S. 2d 833 (Supreme Ct., Monroe Cty. 2000), and that the commission of a violent act during the patient's present psychiatric hospitalization could be used to satisfy the "one or more violent acts" criteria of the law. Matter of Weinstock, 2001 WL 290238 (Supreme Ct. 2001). This case was decided by Justice Cutrona, the same judge who decided Urcuyo, supra.

In cases that have turned on questions of procedure, one court in Queens County has found a doctor's conclusory statements in an affidavit insufficient to satisfy the pleading requirements of the law (and that this failure was a nonwaivable jurisdictional defect), In re Sullivan, 710 N.Y.S. 2 d 853 (Queens Cty. 2000), and another one has found that the physician-patient evidentiary privilege did not prevent a patient's treating psychiatrist from submitting an affidavit or giving testimony in support of the director's petition, In re Sullivan, 710 N.Y.S. 2d 804 (Queens Cty. 2000). A King's County case has concluded that "any instances of non-compliance with treatment, no matter how recent, would be relevant in determining whether or not a patient will be compliant in the future." In re Dailey, 713 N.Y.S. 2d 660 (Supreme Ct. 2000). This case was also decided by Justice Cutrona, the same judge who decided Urcuyo and Weinstock, supra.

${ }^{151} 696$ N.Y.S. 2d 769 (Nassau Cty. 1999).

${ }^{152}$ Id. at 774 . 
Conticchio has not been cited in subsequent cases, so it is not clear what impact, if any, this will have on actual Kendra's Law cases on this question.

In a non-Kendra's Law case that was ancillary to the criminal prosecution of Andrew Goldstein - the individual subsequently convicted of murdering Kendra Webdale, after whom Kendra's Law was named-another court, in the course of a decision ordering the production of records from a private hospital, looked at the language of Kendra's Law to conclude that, in addition to establishing an OPC plan, the law was geared to "improve coordination of care for mentally ill persons living in the community, expand the use of conditional release in psychiatric hospitals, and improve dissemination of information between and among health providers and general hospital emergency rooms."153

What about in non-reported cases? At an Association of the Bar of the City of New York panel discussion in 2000, it was revealed that, of the 163 petitions granted in Kendra's Law cases throughout New York state, 131 of them arose in New York City. ${ }^{154}$ In responding to this information, Westchester County Supreme Court Justice John P. DiBlasi, characterized this large number of petitions granted in New York is a "cause for concern," especially since the burden of proof required to make out a prima facie case under Kendra's Law is so high. ${ }^{155}$ Justice DiBlasi said he was worried that judges - who may be motivated more by protecting the public rather than compelling patients to get needed treatmentmay decide to err on the side of caution. ${ }^{156}$

${ }_{153}^{153}$ City of New York v. Bleuler Psychotherapy Center, Inc., 695 N.Y.S. 2d 903 (N.Y. Cty.
${ }_{154}$ Yael Schacher, Experts Disagree Over the Success of Kendra's Law, N.Y.L.J. (June 30, 2000), at 1. As of February 19, 2001, 591 petitions had been granted in New York City, 22 were denied, and 162 were pending. Memorandum, Paul McNicholas, Office of Management Information Systems, to Isaac Monserrate, NYC Department of Mental Health (Feb. 9, 2001) (on file with author) ("McNicholas Memo").

${ }^{155}$ It has been reported to me that county officials in upstate New York have been criticized by state officials for the relatively low numbers of Kendra's petitions that have been filed.

${ }^{156}$ Schachter, supra. note 155, at 1-2. One of the interesting unreported pieces of Kendra's data is the disparity in New York as to the contestation of Kendra petitions as between different counties. A close study of the data reveals that this cannot be divided easily-as one might imagine-simply between rural and urban areas, or between upstate and downstate. To some extent, the variation in Kendra's Law statistics appears to be a function of venue. Those counties that comprise the Second Department-Brooklyn, Queens, Nassau, Suffolk, and a few others- have, disproportionately, been responsible for far more contested applications than those in the other three departments combined. There have, of course, been many petitions filed in the other boroughs of New York as well. See "McNicholas Memo," supra note 154.

Why has the Second Department been so markedly involved? Sources in that office tell me that their primary concern is the way the law has been implemented: that it may potentially undermine the therapeutic alliance (by undermining individuals' sense of self-esteem and self-importance), see e.g., Paul S. Appelbaum \& Stephen K. Hoge, The Right to Refuse Treatment: What the Research Reveals, 4 Behav. Sci. \& L. 279, 291 (1986); Bruce J. Winick, The Right to Refuse Mental Health Treatment: A Therapeutic Jurisprudence Analysis, 17 InT'L J.L. \& PsyCHIATRY 99, 112 (1994), that due process issues are often slighted, see e.g., Douglas Stransky, Civil Commitment and the Right to Refuse Treatment: Resolving Disputes from a Due Process Perspective, 50 U. Miami L. Rev. 413, 443 (1996), that the question of the stage in the process at which the right to counsel attaches has not been operationally resolved, that police officers can be improperly utilized in the apprehension of allegedly non-compliant Kendra's patients (a subset of cases in which due process is frequently 


\section{Therapeutic Jurisprudence Perspectives}

What are the TJ implications of Kendra's Law? ${ }^{157}$ To be sure, the law is a law professor's dream final exam hypo: what to say about a law that, on its surface, seeks to make mental health services available to an important subset of mentally ill persons - those in danger of deteriorating and running the risk of requiring reinstitutionalization if they do not receive aggressive treatment-but which, when examined more carefully, threatens important civil rights/civil liberties values and perhaps, promises what it cannot possibly deliver. Dr. Howard Owens, for example, is pessimistic: "Lacking both the adequate funding to provide enhanced care and any mechanism for enforcing the court's commitment order. The new law is unlikely to achieve its stated intention ..."

In the most comprehensive, scholarly and exhaustive defense of AOPC laws, Professor Ken Kress argues forcefully:

... In many cases of actual or threatened violence by individuals with mental disorders, an assisted outpatient treatment statute would have protected both the victims and the perpetrator, thereby enhancing public safety and welfare. While

absent, although such cases of alleged non-compliance may result from something as benign as misdelivered clinic appointment notifications, see e.g., Henry Steadman et al., Explaining the Increased Arrest Rate Among Mental Patients: The Changing Clientele of State Hospitals, 135 Am. J. PSYCHIATRY 816, 819-20 (1978) (discussing number of explanations for increasing arrest rate among former mental patients and concluding that composition of state hospitals reflects an inpatient population with higher likelihood of post-release arrest); see generally, Ellen Steury, Criminal Defendants with Psychiatric Impairment: Prevalence, Probabilities, and Rates, 84 J. CRIM. L. \& CRIMINOL. 352 (1993)), that court orders may have an inevitably self-generating coercive effect (see e.g., Margaret Cordray, Contempt Sanctions and the Excessive Fines Clause, 76 N.C.L. Rev. 407 (1998)), (and the fact that courts logically and accurately expect that individuals will want to comply with court orders, see e.g., Bruce Ledewitz, Civil Disobedience, Injunctions, and the First Amendment, 19 Hofstra L. Rev. 67, 111 (1990); Susan Sturm, Resolving the Remedial Dilemma, 138 U. PA. L. Rev. 805, 912 (1990)), that the extent of drug side-effects may be ignored, see generally, 2 PERLIN, supra note 6 , § 3B-1 et seq., that the commitment net may be extended too broadly, see Michael L. Perlin, Competency, Deinstitutionalization, and Homelessness: A Story of Marginalization, 28 Hous. L. REv. 63, 125 (1991), that Kendra's Law conflicts with the heart of the Rivers decision, see supra text accompanying notes 130-38, and, finally, the way that the law depends, inevitably, on the good will of those vested with its enforcement. Interestingly, this latter topic appears in the law review literature only in articles dealing with questions of international law. See e.g., Martha Jean Baker, The Different Voice: Japanese Norms of Consensus and "Cultural" Feminism, 16 UCLA PAC. BAsIN L.J. 133, 135 (1997); Katherine M. Culliton Finding a Mechanism to Enforce Women's Right to State Protection From Domestic Violence in The Americas, 34 HaRv. INT'L L.J. 507, 529 n. 101 (1993).

This information reifies an intuition I have had since my first contact with TJ a decade ago: that it is impossible, in any area of mental disability law, at least, to even conceptualize TJ questions, issues, problems and solutions, without looking closely at the role of counsel. See 1 PerLin, supra note 6 , $\S 2 \mathrm{~B}-1$ et seq. It is probably even more critical in cases involving Kendra's Law when so many of the critical issues are obscured from public view.

Much of the information in this footnote comes from personal communications with Sidney Hirschfeld, Esq., Mental Hygiene Legal Services, Mineola, NY (April 24, 2001).

157 This is a question that has been rarely addressed. But see, Howard Owens, Outpatient Commitment Comes to New York, 42 Bulletin, NY State Psychiatric Ass'N (Winter 1999-2000), at 8; Susan Pollett, Has Kendra's Law Been a Boon or a Bust?, N.Y.L.J. (Oct. 23, 2000), at 1.

${ }^{158}$ Owens, supra note 157 , at 8. 
the ways in which society's welfare will be enhanced are obvious, the perpetrator's welfare will be enhanced because the perpetrator will not be subject to violent action in self defense, to criminal charges, or to agonizing remorse for his or her actions. ${ }^{159}$

But I am not at all sure that this has happened in Kendra's Law cases.

Kendra's Law, in its current iteration, appears to have both therapeutic and anti-therapeutic aspects. First, publicity about Kendra's Law may lead some persons with mental illness to seek needed treatment that they might not otherwise receive. Also, Kendra's Law is, in many ways, a less restrictive alternative to inpatient hospitalization for certain persons with mental illness who do not voluntarily seek treatment. Because such persons will not be subject to hospitalization, treatment may be more effective and the person may be more likely to adhere to the treatment plan. It may also give the person a sense of control over her treatment, and a sense of independence hospitalized persons may not have.

The involvement of the judicial system may, potentially, be another therapeutic aspect of Kendra's Law. The fact that there is some sort of judicial process - and the right to counsel-may eliminate some measure of inappropriate administrative discretion, and may give some sort of assurance that the person's constitutional and legal rights are being upheld, and that the process is being conducted in a fair manner. ${ }^{160}$ These outcomes certainly have potentially therapeutic impacts. ${ }^{161}$ Finally, a recent study of AOPC in another jurisdiction suggests that such laws may significantly reduce the level of victimization of persons with mental illness. ${ }^{162}$ If this is to be borne out in subsequent studies (the cohort members were all participants in a program at Duke University, and thus subject to North Carolina's AOPC laws, not New York's), it may prove to have great importance to the future of AOPC elsewhere.

On the other hand, there are many aspects of Kendra's Law that strike me as fundamentally anti-therapeutic. The fact that none of the long list of questions that I earlier raised ${ }^{163}$ has been resolved is extraordinarily problematic, given the range of issues involved, and the fundamentality of those questions as to the operation of the law and its impact on persons with mental illness. Certainly, one of the most critical issues-once again-is that raised by the way it apparently flies in the face of the Rivers decision ${ }^{164}$ Although Matter of Urcuyo ${ }^{165}$ has upheld Kendra's Law against the first trial court-level Rivers challenge, that

${ }^{159}$ Ken Kress, An Argument for Assisted Outpatient Treatment for Persons with Serious Mental Illness Illustrated with Reference to a Proposed Statute for Iowa, 85 IowA L. REv. 1269, 1283 (2000).

${ }^{160}$ Persons with mental illness have the same innate sense of "procedural justice" as do others. See Tyler, supra note 52, at 442-44.

${ }_{161}$ See Perlin, Healing, supra note 3, at 415-16.

162 Virginia Hiday et al., Victimization: A Link Between Mental Illness and Violence, 24 InT'L

J. L. \& PSychiatry 559 (2001).

163 See supra text accompanying notes 103-45.

164504 N.Y.S. 2 d 74 (1986).

165714 N.Y.S. $2 d 862$ (Sup. Ct. 2000). See supra text accompanying notes 147-50. 
decision is, to my mind, utterly unpersuasive, and in no way resolves the Rivers-related questions raised earlier.

I am also gravely concerned about the way that Kendra's Law blurs the relationship between civil and criminal mental disability law. By widening the net of persons who can come within the ambit of the public mental health system, by investing certain prison and parole officers with putative mental health "expertise," and by making it appear to the public that there is a causal connection between mental illness and dangerousness, ${ }^{166}$ Kendra's Law may distort-even further-the public's view of persons with mental illness.

Kendra's Law may also be too easy of an alternative to involuntary civil commitment. Certainly, many of the persons who come within its ambit are perceived as "undesirable," and persons who many would rather simply see locked away, people that they want off the street. ${ }^{167}$ Another troubling aspect of Kendra's Law is the fact that a treatment order can be rendered without the individual actually being present in court. ${ }^{168}$ If the person's presence cannot be secured, after attempts having been made, the court may proceed without the person being present. The statute does not define how many attempts must be made, or what can be considered a reasonable attempt. It is vague and ambiguous, and leads to the danger of a significant number of these Kendra's Law treatment orders being handed down in absentia. This raises profound antitherapeutic implications.

Finally, the most recent broad-based studies conclude that, while there is some evidence of improved outcomes for people with severe mental illness under involuntary outpatient treatment, that that evidence only emerges when the court order is combined with intensive mental health services. The study-commissioned by the RAND Institute for Civil Justice on behalf of the California legislature-concluded that, "there is no evidence that a court order alone helps achieve compliance or good outcomes." 169

166 See Perlin, supra note 58.

${ }^{167}$ I discuss this extensively in Michael L. Perlin, "Half-Wracked Prejudice Leaped Forth": Sanism, Pretextuality, and Why and How Mental Disability Law Developed As It Did, 10 J. ConTEMP. LEG. Iss. 3, 8 (1999):

... [A] New York Times ... article dealt with an ex-patient, Gerald Kerrigan, who wandered the streets of the Upper West Side of Manhattan. Kerrigan never threatened or harmed anybody, but he was described as "different," "off," "not right," somehow. It made other residents of that neighborhood-traditionally home to one of the nation's most liberal voting blocs -- nervous to have him in the vicinity, and the story focused on the response of a community block association to his presence. The story hinted darkly that the social "experimentation" of deinstitutionalization was somehow the villain.

.... Kerrigan was [seen as] emblematic of a major "social problem." [His] story reflected the failures of "deinstitutionalization" and demonstrated why the application of civil libertarian concepts to the involuntary civil commitment process was a failure... No one discussed Gerald Kerrigan's autonomy values (or the quality of life in the institution from which he was released).

168 N.Y. Ment. Hyg. L. $\$ 9.60$ (E) (3) (II).

169 http://www.rand.org/hot/Press/ca.mental.html (visited April 24, 2001). 


\section{Conclusion}

Writing over 2 years ago about Kendra's Law, I concluded:

Kendra's Law-like so many mental health laws ${ }^{170}$ — was enacted in response to a vivid case ${ }^{171}$ that appeared to be the inevitable outcome of flawed social policies (or, at the least, the mis-implementation of questionable social policies). The new law is ambitious, but leaves many questions unanswered-questions of law, of social policy, of clinical decisionmaking and of governmental operation. ${ }^{172}$

In the time that has passed since I wrote that paper, little has happened to change my mind. And, although there are a few therapeutic glimmers to be sighted-if Kendra's Law is read most optimistically-I remain convinced that it is the wrong answer to a difficult and intractable problem.

${ }^{170}$ On the use of the "slip-through-the-cracks" metaphor in mental health law, see Michael L. Perlin, Unpacking the Myths: The Symbolism Mythology of Insanity Defense Jurisprudence, 40 CASE W. Res. L. Rev. 599, 635-36 (1990).

${ }^{171}$ On the way that "a single vivid case can shape (or misshape) legislative policies in the mental disability area," see Michael L. Perlin, The ADA and Persons with Mental Disabilities: Can Sanist Attitudes Be Undone?, 8 J.L. \& Health 15, 44 (1993-94).

${ }^{172}$ Michael L. Perlin, Outpatient Commitment: Panacea or Pandora's Box (prepared for presentation to the NYS Office of Court Administration Yearly Legal Update, Rochester, NY, Nov. 1999) (paper on file with author). 